\title{
Keanekaragaman dan Pemanfaatan Tanaman Pekarangan di Desa Taripa, Kecamatan Pamona Timur, Kabupaten Poso, Sulawesi Tengah
}

\section{(Diversity and Utilization of Yard Plants in Taripa Village, East Pamona District, Poso Regency, Central Sulawesi)}

\author{
Vanda Evanglin Tobondo*, Roni Koneri**, Dingse Pandiangan \\ Jurusan Biologi, FMIPA Universitas Sam Ratulangi, Manado 95115 \\ *Email korespondensi: vandatobondo846@gmail.com;** ronicaniago@unsrat.ac.id
}

(Article History: Received January 14, 2021; Revised February 15, 2021; Accepted February 28, 2021)

\begin{abstract}
ABSTRAK
Pekarangan merupakan sebidang tanah yang di atasnya terdapat bangunan tempat tinggal dan dapat dibudidayakan berbagai spesies tanaman. Penelitian ini bertujuan menganalisis keanekaragaman dan pemanfaatan tanaman pekarangan di Desa Taripa, Kecamatan Pamona Timur, Kabupaten Poso, Sulawesi Tengah. Pengambilan sampel berdasarkan luas pekarangan yaitu kategori sempit (100-200 $\left.\mathrm{m}^{2}\right)$, sedang $\left(300-400 \mathrm{~m}^{2}\right)$ dan luas $\left(500-600 \mathrm{~m}^{2}\right)$. Pada setiap kategori diambil 10 sampel pekarangan dan dicatat seluruh spesies tanaman yang terdapat pada pekarangan tersebut. Pemanfaatan tanaman ditentukan berdasarkan alasan penanaman dengan wawancara langsung dengan pemilik pekarangan. Analisis data meliputi kelimpahan, indek kekayaan, indek keanekaragaman dan indek kemerataan spesies tanaman. Hasil didapatkan sebanyak 64 famili yang terdiri dari 155 spesies dan 1265 individu. Famili yang banyak ditemukan jumlah spesiesnya adalah Araceae. Spesies yang memiliki kelimpahan tertinggi yaitu Garcinia mangostana dan Curcuma longa. Kelimpahan spesies tertinggi pada lahan pekarangan katagori luas. Keanekaragaman dan kekayaan spesies tanaman tertinggi pada lahan pekarangan kategori sempit, sedangkan kemerataan pada lahan kategori sedang. Habitus tanaman yang banyak dimanfaatkan adalah herba. Organ tanaman yang dimanfaatkan umumnya daun, sedangkan pemanfaatan tanaman pekarangan banyak digunakan sebagai sumber pangan.
\end{abstract}

Kata kunci: Keanekaragaman; Garcinia mangostoma; herba; daun.

\section{ABSTRACT}

Yard is a plot of land on which there are residential buildings and various plant species can be cultivated. This research aims to analyze the diversity and utilization of garden plants in Taripa Village, East Pamona District, Poso Regency, Central Sulawesi. Sampling was based on the area of the yard, namely the narrow (100-200 $\left.\mathrm{m}^{2}\right)$, medium $\left(300-400 \mathrm{~m}^{2}\right)$ and broad $\left(500-600 \mathrm{~m}^{2}\right)$. In each category, 10 samples of the yard were taken and recorded all plant species found in the yard. The use of plants is determined based on the reasons for planting by direct interviews with the owners of the yards. Data analysis includes abundance, Richness index, diversity index and index evenness of plant species. The results obtained were 64 families consisting of 155 species and 1265 individuals. The family with the most number of species found is Araceae. The species that had the highest abundance were Garcinia mangostana and Curcuma longa. The highest species abundance was in the large yard area. The highest diversity and richness of plant species was in the narrow category land, while evenness was in the medium category. Plant habitus that is widely used is herbaceous. The plant organs that are used are generally leaves, while the use of garden plants is widely used as a food source.

Key words: Diversity; Garcinia mangostoma; herb; leaf. 


\section{PENDAHULUAN}

Potensi sumber daya tumbuhan yang ada di Indonesia merupakan aset dengan nilai keunggulan komparatif dan merupakan modal dasar untuk pemanfaatan dan pengembangannya untuk dapat menjadi komoditif yang kompetitif. Keanekaragaman tumbuhan dapat dimanfaatkan dan dilestarikan karena sangat berpotensial untuk dapat dikembangkan dengan melibatkan masyarakat yang memiliki pengetahuan tersebut (Rahayu 2005).

Keanekaragaman tumbuhan di pekarangan akan menciptakan kelestarian lingkungan hidup pada pekarangan. Pemeliharaan tumbuhan di pekarangan merupakan salah satu cara upaya konservasi tumbuhan secara ex-situ. Konservasi ex-situ merupakan pelestarian keanekaragaman hayati di luar habitatnya (Kasso dan Balakrishnan 2013). Konservasi keanekaragaman hayati meliputi tiga kegiatan penting yaitu penelitian, pemanfaatan, dan perlindungan. Konservasi ex situ dapat berupa kebun raya, kebun binatang dan gene banks (Kasso dan Balakrishnan 2013), namun pekarangan dapat digunakan sebagai lahan konservasi yang diberi istilah backyard konsevasi (Silalahi 2018).

Lahan pekarangan memiliki fungsi multiguna yang dapat menghasilkan berbagai bahan pangan seperti umbiumbian, buah-buahan, sayur, tanaman obat, bahan tanaman rempah dan bahan kerajinan tangan. Hampir setiap pekarangan rumah terdapat tanaman yang dibudidayakan atau dikembangkan sesuai dengan manfaat tanaman tersebut. Berdasarkan jenis pemanfaatan tanaman dapat diklasifikasikan sebagai tanaman hias, tanaman buah, tanaman sayuran, tanaman obat, tanaman bumbu, tanaman penghasil pati, tanaman industri, tanaman peneduh dan tanaman-tanaman penghasil pakan, kayu bakar, bahan kerajinan tangan dan manfaat lain (Arifin et al. 2009). Pekarangan juga berperan penting dalam pemenuhan kebutuhan hidup sehari-hari, meningkatkan pendapatan penduduk, memberikan keindahan dan kenyamanan dan sebagai penyaring udara serta peredam suara kebisingan (Mukarlina et al. 2014).

Keanekaragaman tanaman pekarangan dan pemanfaatnnya di Sulawesi Tengah sudah pernah diteliti, tapi masih sedikit publikasi tentang hal tersebut. Karina (2014) meneliti tentang jenis tumbuhan berguna pada pekarangan masyarakat percampuran di Kelurahan Layana Indah Kecamatan Palu Timur Sulawesi Tengah. Pemanfaatan lahan pemukiman untuk ditanami berbagai spesies tanaman perlu dilakukan agar keanekaragaman hayati pada lahan pekarangan tetap tinggi dan produksi pertanian dapat dipertahankan. Keanekaragaman dan pemanfaatan tanaman pekarangan di Desa Taripa, Kecamatan Kecamatan Pamona Timur, Kabupaten Poso belum pernah diteliti dan dipublikasikan. Penelitian ini bertujuan untuk menganalisis keanekaragaman dan pemanfaatan tanaman pekarangan di Desa Taripa, Kecamatan Pamona Timur, Kabupaten Poso.

\section{METODE}

Penelitian ini dilaksanakan dari bulan Oktober-Desember 2020. Lokasi penelitian bertempat pada lahan pekarangan di Desa Taripa Kecamatan Pamona Timur, Kabupaten Poso. Penentuan lokasi penelitian dilakukan dengan metode purposive sampling yakni berdasarkan kategori luas pekarangan. Luas pekarangan yang dijadikan sampel dikelompokkan atas tiga kategori yaitu tergolong sempit (100$\left.200 \mathrm{~m}^{2}\right)$, sedang $\left(300-400 \mathrm{~m}^{2}\right)$ dan luas $\left(500-600 \mathrm{~m}^{2}\right)$. Pada masing-masing kategori luas pekarangan diambil 10 sampel pekarangan sehingga total sampel sebanyak 30 pekarangan. Pada setiap pekarangan yang dijadikan sampel dicatat seluruh spesies tanaman yang tumbuh di pekarangan tersebut, serta jumlah tanaman untuk setiap spesies. Jika tanamannya berumpun maka satu rumpun dihitung berjumlah satu untuk spesies tersebut. 
Pemanfaatan tanaman pekarangan ditentukan berdasarkan alasan penanaman atau pemanfaatan tanaman oleh pemilik pekarangan. Teknik yang dilakukan adalah wawancara langsung dengan pemilik pekarangan. Manfaat tanaman pekarangan dibagi menjadi empat kategori yaitu tanaman hias, tanaman pangan, tanaman untuk obat-obatan dan tanaman untuk diperdagangkan

Analisis data meliputi perhitungan kelimpahan, indeks kekayaan spesies, indek keanekaragaman spesies dan indek kemerataan spesies. Kelimpahan spesies merupakan jumlah individu pada suatu spesies tanaman. Indek kekayaan dihitung dengan rumus:

$$
\mathrm{R}=\frac{S-1}{\operatorname{In}(N)}
$$

R: Indeks kekayaan spesies; S: jumlah total spesies; N: jumlah total individu (Fachrul 2012).

Indek keanekaragaman spesies ditentukan dengan rumus Shanon-Weiner:

$$
H^{\prime}=-\sum\{(p i) \ln (p i)\}
$$

H': Indeks keanekaragaman, Pi: Proporsi jumlah individu ke-i (ni/N), ni: Kelimpahan spesies ke-I; N: Kelimpahan total spesies yang ditemukan, $\Sigma$ : Jumlah (Fachrul 2012).

Indeks kemerataan (E) dihitung dengan persamaan:

$$
\mathrm{E}=\frac{H^{\prime}}{\operatorname{Ln} S},
$$

E: Indeks kemerataan, H': Indeks keanekaragaman; S: Jumlah spesies (Mangurran 2004).

\section{HASIL DAN PEMBAHASAN Pekarangan}

Struktur dan Komposisi Tanaman

Hasil penelitian tanaman pekarangan di Desa Taripa didapatkan sebanyak 64 famili yang terdiri dari 155 spesies dan 1265 individu. Famili yang paling banyak ditemukan jumlah spesiesnya adalah Araceae (12 spesies), kemudian berikutnya Liliaceae (9 spesies). Spesies yang memiliki kelimpahan tertinggi yaitu Garcinia mangostana dengan jumlah 48 individu $(3,79 \%)$ dan Curcuma longa sebanyak 37 individu (2,92\%) (Lampiran 1).

Araceae merupakan famili yang banyak jumlah spesiesnya. Famili Araceae yang ditemukan diantaranya adalah tanaman aglonema (Aglaonema crispum), aglonema evergreen (Aglaonema commutatum), air mata bunda (Sedum morganianum), tanaman dolar (Zamioculcas zamiifolia), gelombang cinta (Anthurium plowmanii) dan janda bolong (Monstera adansonii). Spesies tersebut merupakan tanaman hias yang banyak ditemukan di Desa Taripa terutama spesies aglonema. Karakteristik kunci famili Araceae adalah perbungaan yang tersusun dalam bentuk tongkol (spadix) yang dikelilingi oleh seludang (spathe) (Sinaga et al. 2017).

Spesies tanaman dengan jumlah paling banyak dan didapati pada semua kategori luas pekarangan adalah manggis (Garcinia mangostana), selanjutnya adalah kunyit (Curcuma longa), jahe (Zingiber officinale), seledri (Apium graveolens), daun bawang (Allium fistulosum) yang merupakan tanaman rempah yang dapat sekaligus sebagai obat. Berdasarkan pengolongan tiap kategori luas pekarangan maka tanaman yang paling banyak ditemukan pada pekarangan kategori luas dan kategori sedang adalah manggis (Garcinia mangostana). Pada pekarangan kategori sempit terdapat dua spesies tanaman yaitu manggis (Garcinia mangostana) dan seledri (Apium graveolens).

Tanaman andong (Cordyline fruticosa) memiliki variasi daun yang banyak hal ini membuatnya banyak digemari dan dijadikan tanaman hias. Tanaman andong juga dijadikan sebagai tanaman hias, pembatas wilayah tanah. Tanaman andong juga sering digunakan saat tarian daerah poso berlangsung, dan tanaman ini sering dipegang penari pada saat tarian. Menurut Zurriyati dan Dahono (2016), keberadaan 
sumber daya genetik suatu tanaman juga erat kaitannya dengan tradisi masyarakat.

Mangis merupakan tanaman yang memilki kelimpahan tertinggi yang ditemukan di lahan pekarangan desa Taripa. Banyaknya tanaman manggis ditemukan karena manggis memiliki banyak manfaat baik sebagai penunjang kebutuan nutrisi maupun vitamin dan menyembuhkan beragam jenis penyakit yang diantaranya adalah jantung koroner. Tanaman manggis terutama buahnya banyak diperjual belikan oleh masyarakat setempat, serta keberadaan pohon membantu keestetikaan pekarangan. Menurut Widiastuti et al. (2010) manggis (Garcinia mangostana) adalah komoditas buah asli indonesia dan merupakan salah satu buah tropis yang sangat terkenal, dan memiliki rasa buahnya yang lezat dan banyak digemari. Manggis juga telah lama dimanfaatkan sebagai obat-obatan diantaranya sebagai anti inflamasi, antibakteri, serta sebagai perlakuan terhadap infeksi dan luka (Chen et al. 2008; Chomnawang et al. 2009; Obolskiv et al. 2009).

Tanaman yang dibudidayakan di pekarangan pada umumnya sebagian besar merupakan tanaman yang ingin diambil manfaatnya secara langsung oleh pemilik pekarangan, terutama perolehan gizi dari tanaman pekarangan. Hal ini sesuai dengan penelitian lain yang menyatakan bahwa keragaman tanaman pekarangan yang memberi manfaat gizi yang baik sangat ditentukan oleh preferensi anggota pemilik pekarangan (Galluzzi et al. 2010). Semakin banyak manfaat yang didapatkan masyarakat pada tanaman maka akan semakin banyak tanaman tersebut kita temukan di pekarangan.

\section{Keanekaragaman Tanaman Pekarangan di Desa Taripa}

Hasil pengamatan menunjukan ada perbedaan kelimpahan tanaman pada setiap kategori luas pekarangan. Kelimpahan tanaman pekarangan tertinggi terdapat pada lahan pekarangan kategori luas yaitu 474 individu, sedangkan terendah pada pekarangan kategori sedang yaitu sebesar 365 individu (Gambar 1a). Pekarangan dengan kategori luas memiliki kelimpahan tinggi hal ini tentunya didukung dengan wilayah pekarangan yang luas sehingga dapat ditanami banyak tanaman.

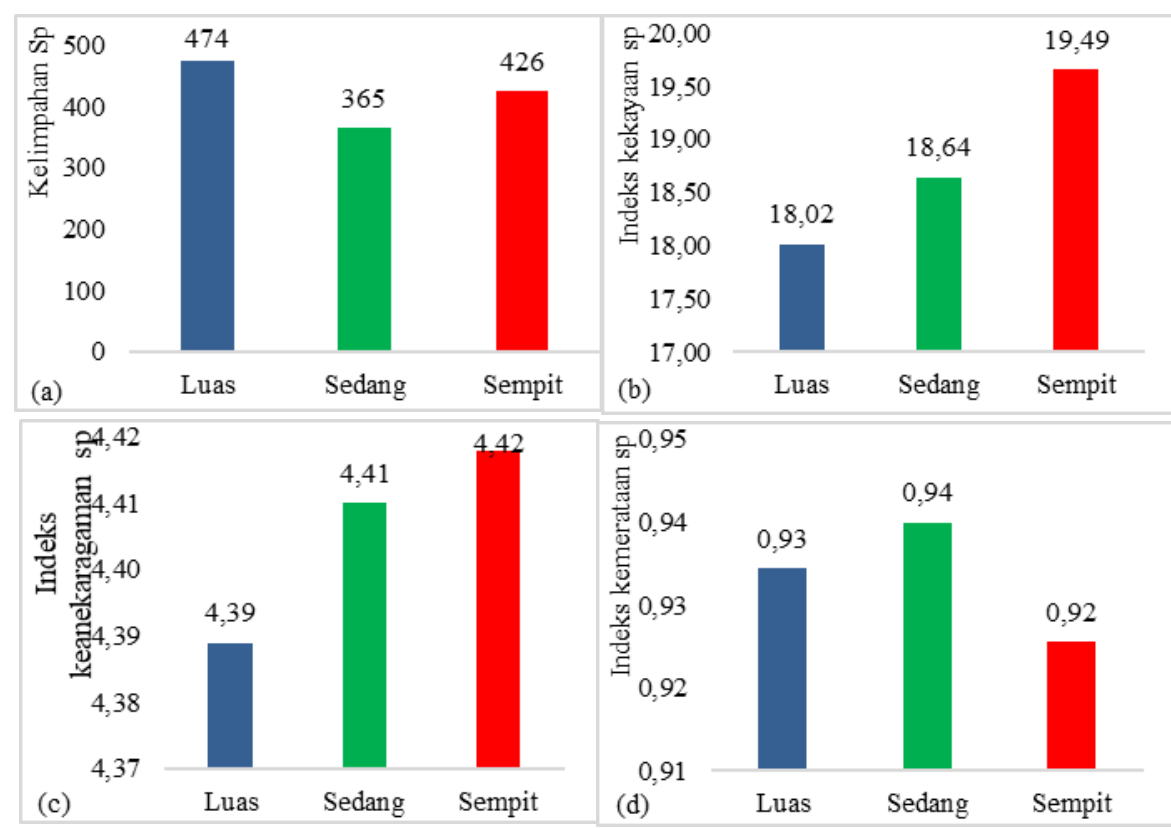

Gambar 1. Kelimpahan spesies (a), Indek kekayaan spesies (b), Indek Keanekaragaman spesies (c), dan Indek kemerataan spesies (d) tanaman pekarangan berdasarkan kategori luas pekarangan di Desa Taripa. 
Indek kekayaan dan indek keanekaragaman spesies tanaman pekarangan tertinggi pada lahan sempit dan terendah pada lahan kategori luas. Indek kemerataan spesies tertinggi pada lahan pekarangan sedang dan terendah pada lahan pekarangan sempit (Gambar 1).

Tingginya indeks kekayaan dan indek keanekaragaman spesies disebabkan oleh tingginya jumlah spesies dan jumlah individu setiap spesies yang ditemukan selama pengamatan pada masing-masing kategori luas pekarangan di Desa Taripa. Walaupun demikian didapatkanya nilai indeks keanekaragaman berbeda di masingmasing kategori. Adanya perbedaan nilai indeks tersebut disebabkan oleh perbedaan jumlah masing-masing spesies yang ditemukan di setiap kategori pekarangan. Keanekaragaman spesies yang tinggi pada pekarangan sedang dan sempit disebabkan karena pekarangan sedang dan sempit lebih banyak ditanami berbagai spesies tumbuhan.

Hal ini berbeda dengan penelitian Pendong dan Arrinjani (2004) yang melaporkan bahwa pertambahan luas lahan pekarangan efektif cenderung juga meningkatkan jumlah spesies dan individu tanaman pada pekarangan. Semakin luasnya pekarangan maka lebih banyak spesies tanaman yang dapat ditanami penduduk dipekarangan. Pada kategori pekarangan luas jumlah individu yang didapatkan tinggi namun untuk jumlah spesies masih kurang dibandingkan dengan kategori pekarangan sempit dan sedang.

Indeks keanekaragaman dapat digunakan sebagai bioindikator yang dapat menggambarkan bagaimana kestabilan sebuah ekosistem. Indeks keanekaragaman tanaman yang bernilai besar atau kecilnya dapat memberi petunjuk besarnya daya dukungan ekosistem terhadap pemukiman. Odum (1998) menyatakan bahwa keanekaragaman spesies merupakan fungsi dari keanekaragaman ruang tumbuh. Apabila suatu wilayah hanya didominasi oleh spesies-spesies tanaman tertentu maka wilayah tersebut memiliki keanekaragamanspesies yang rendah.

Pemilik pekarangan menanam tanaman yang bervariasi spesies dan manfaatnya, sehingga dalam suatu pekarangan tidak ada penguasaan oleh satu spesies tumbuhan saja. Indek keanekaragaman yang tinggi maka suatu komunitas tumbuhan akan semakin stabil sehingga dapat bersaing dalam mengambil nutrisi dan unsur hara yang menggambarkan adanya kestabilan suatu komunitas (Mukarlina et al. 2014).

Sesuai dengan data yang didapatkan jika dibandingkan dengan penelitian Murklina et al (2014) di Desa Pahauman, Kalimantan Barat di pekarangan sempit memiliki keanekaragaman rendah $(0,87)$ dibandingkan dengan pekarangan sedang $(4,05)$ dan pekarangan luas $(3,99)$. Sementara untuk hasil yang didapatkan semua indeks memiliki nilai >3 yang berarti semua hasil memiliki keanekaragaman yang tinggi walaupun nilai indeks kategori pekarangan sedang dan sempit lebih besar dari kategori pekarangan luas hal ini dikarenakan pekarangan sedang dan sempit memiliki jumlah spesies yang lebih banyak.

Nilai indeks kemerataan spesies tanaman pekarangan di Desa Taripa yaitu pekarangan sempit 0,92, pekarangan sedang 0,94 dan untuk pekarangan luas sebesar 0,93 . Hasil menunjukan semua nilai indeks kemerataan tanaman pekarangan di Desa Taripa mendekati satu yang berarti penyebaran tiap spesies merata.

Penyebab tingginya nilai kemerataan dari spesies tanaman pekarangan yang ditanam pada setiap lokasi pekarangan di Desa Taripa karena spesies-spesies tersebut merupakan kelompok tanaman yang dapat memberikan manfaat yang relatif sama bagi penduduk setempat dan lingkungan sekitarnya. Spesies tanaman yang ditemukan di setiap lokasi berdasarkan kategori luas pekarangan diantaranya adalah bunga begonia (Begonia cucullate), puring (Codiaeum variegatum), manggis (Garcinia mangostana), dan daun bawang (Allium fistulosum). 
$\begin{array}{ccc}\text { Besarnya } & \text { nilai kemerataan } & \text { spesies } \\ \text { tanaman } & \text { dipengaruhi } & \text { indek }\end{array}$ keanekaragaman spesies tanaman tersebut. Semakin besar indek keanekaragaman spesies tanaman maka akan semakin besar pula indek kemerataan dari spesies tanaman tersebut atau berbanding lurus (Soewito 1987).

\section{Pemanfaatan Tanaman Pekarangan di Desa Taripa}

Berdasarkan wawancara dengan masyarakat mengenai manfaat tanaman pekarangan maka spesies tanaman yang ada di lahan pekarangan di Desa Taripa dapat dikategorikan sebagai tanaman pangan. Tanaman pangan yang terdapat di pekarangan meliputi buah-buahan, sayuran, rempah-rempah dan pakan ternak. Pada pekarangan juga terdapat tanaman hias tanaman obat dan tanaman yang diperdagangkan seperti kerajinan tangan, tanaman yang bernilai ekonomis (Lampiran 2). Tanaman produksi di lahan pekarangan hasilnya dapat dimanfaatkan sendiri maupun dijual sehingga dapat memberikan tambahan pendapatan bagi masyarakat. Secara umum masyarakat Desa Taripa telah memanfaatkan pekarangan sebagai penunjang kebutuhan hidup baik sebagai penambahan pendapatan, membantu memenuhi kebutuhan pangan sehari-hari, kebutuhan obat ataupun menyepurnakan keestikaan pekarangan rumah.

Pemanfaatan lahan pekarangan dengan baik seperti menanam tumbuhan bernilai ekonomis memiliki peran yang cukup besar manfaatnya dalam meningkatkan taraf hidup sebagian besar masyarakat di Indonesia. Di beberapa daerah, terutama di wilayah pedesaan usaha pertanian di lahan pekarangan umumnya di arahkan untuk memenuhi sumber pangan setiap hari. Sesuai dengan pernyataan Abdiyani (2008) bahwa tumbuhan memiliki peran sangat penting dalam ekosistem, antara lain pengurangan erosi, membantu siklus hara, sebagai sumber plasma nutfah, peningkatan infiltrasi, bahan bangunan, sumber obat- obatan, pakan ternak dan satwa hutan, serta manfaat lainnya yang belum diketahui.

Tanaman hias lebih banyak ditanam pada bagian depan halaman rumah. Hal ini guna memberikan nilai estetika atau keindahan rumah. Tanaman yang dimanfaatkan sebagai tanaman hias merupakan tanaman yang memiliki struktur bunga atau daun atau batang yang menarik sehingga dapat dinikmati dari keindahan yang dilihat dari bentuk maupun warnanya untuk dapat memberikan kesenangan atau kepuasan.

Tanaman pangan pada umumnya lebih banyak ditanam pada bagian samping rumah ataupun bagian belakang rumah. Selain guna melindungi rumah dari cahaya matahari langsung tanaman pangan juga dapat menambah penghasilan keluarga. Untuk tanaman rempah dapat digunakan sebagai bumbu masak sehari-hari dan tanaman obat untuk mengobati anggota keluarga.

Kebutuhan karbohidrat masyarakat Indonesia terutama tergantung pada beras, sedangkan masih ada sember lain seperti jagung, ubi jalar, singkong, talas dan sagu sebagai makanan pokok di beberapa daerah. Jagung merupakatan tanaman yang juga ditemui di Desa Taripa sebagai penghasil karbohidrat yang baik dapat mengganti nasi sebagai pangan pokok.

Manggis pertumbuhanya dominan di Desa Taripa tentunya karena memiliki banyak manfaat seperti buahnya sebagai penambah vitamin banyak digemari penduduk setempat karena dari segi ekonomi lebih menguntungkan serta dapat menghasilan buah sepanjang musim sehingga dapat memberi tambahan pendapatan bagi petani dan kulit buahnya dapat direbus untuk digunakan sebagai obat. Pepaya yang buahnya lazim sebagai pelengkap menu makanan, sedangkan bunga dan daunnya sebagai sayur juga berkhasiat sebagai obat tradisional untuk penyakit malaria, dan utuk ubi jalar umbinya yang dapat dikomsumsi juga daunnya digunakan untuk pakan ternak. Pemanfaatan tanaman pangan dengan baik 
merupakan potensi untuk peningkatan penganekaragaman konsumsi pangan serta kualitas gizi, terutama vitamin dan serat (Mitchell dan Hanstad 2004).

Habitus tanaman pekarangan yang ditemukan pada penelitian ini sangat beragam. Habitus yang paling banyak ditemukan adalah herba sebanyak 95 spesies tanaman herba (Gambar 2a). Beberapa contoh tanaman yang berhabitus herba aglonema evergreen (Aglaonema commutatum), amarilis (Proiphys amboinensis), cabai rawit (Capsicum frutescens), jahe (Zingiber officinale).

Tanaman herba banyak ditemukan karena tanaman berhabitus herba atau tanaman yang berukuran lebih kecil maka lahan pekarangan dapat ditumbuhi lebih banyak tanaman, sesuai dengan manfaat yang diperlukan pemilik pekarangan. Banyaknya tanaman hias dan beberapa tanaman pangan seperti rempah-rempah serta obat-obatan yang berhabitus herba membuat tanaman herba banyak dijumpai. Herba adalah tumbuhan yang berbatang basah dan pada umumnya memiliki tinggi kurang lebih sekitar satu meter. Tanaman berhabitus herba membutuhkan lahan yang sempit dibandingkan habitus lainnya. Tanaman herba yang biasanya diperjual belikan sebagian digunakan sebagai penutup tanah seperti rumput jepang dan kacang hias guna keestetikan (Sihotang at al. 2019).

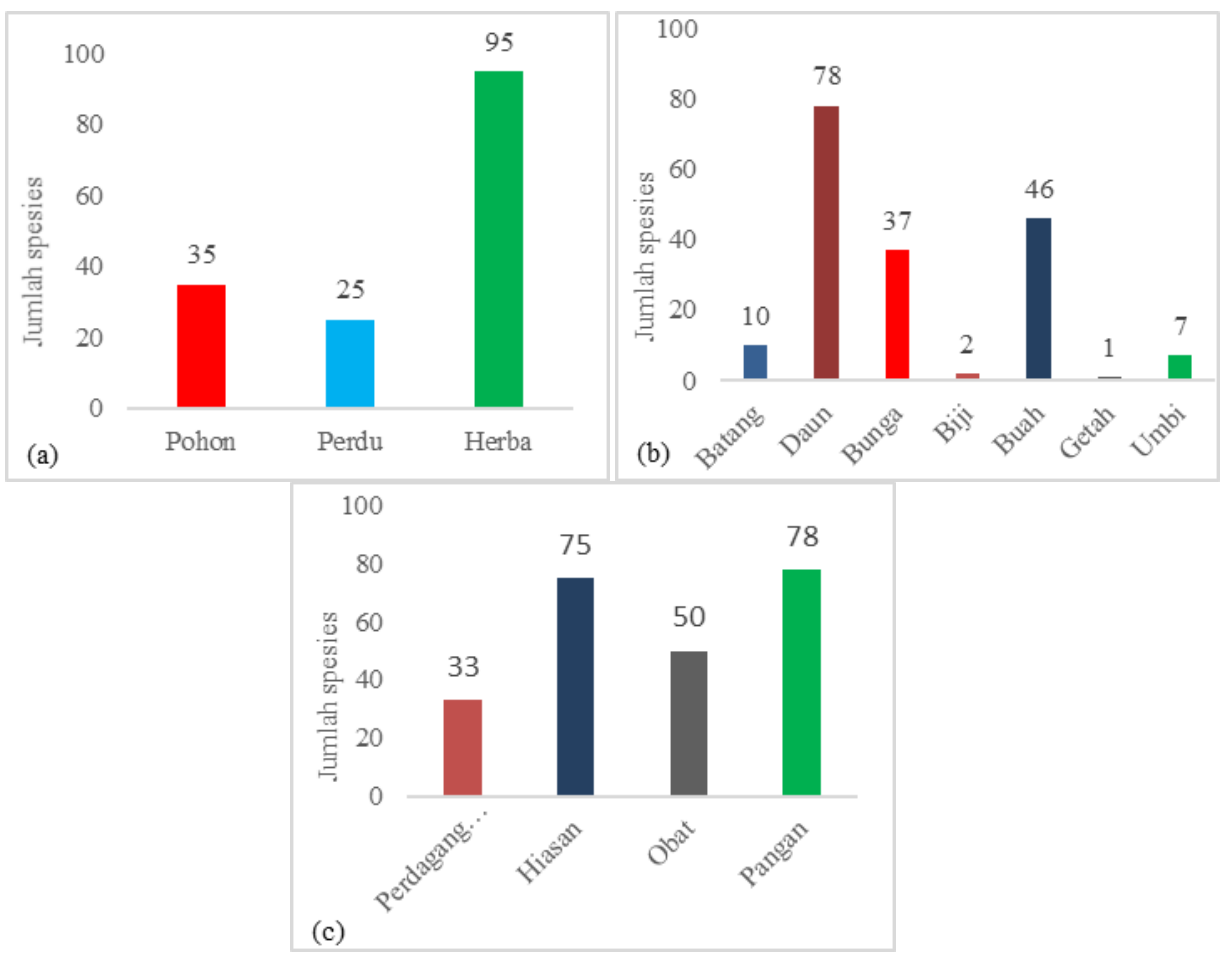

Gambar 2. Pemanfaatan tanaman pekarangan berdasarkan habitus tanaman (a), bagian tanaman yang dimanfaatkan (b), jenis pemanfaatan tanaman (c) di Desa Taripa.

Semakin beragamnya spesies tanaman dalam sutu pekarangan maka produksi dan keuntungannya akan semakin besar (Pandey et al. 2007). Tanaman berhabitus pohon umumnya memiliki ukuran diamater batang yang relatif besar dan lebih banyak menempati lahan pekarangan, tanaman buahan yang berhabitus pohon lebih banyak adalah tanaman tahunan sehingga memudahkan dan membantu penduduk untuk meningkatkan pendapatan ekonomi. Menurut Carpenter (1990) tipe pohon penting untuk ekosistem karena memiliki fungsi tanaman lanskap di antaranya sebagai pengendali erosi, pengendalian iklim dan habitat satwa. Kualitas udara 
pedesaan yang masih baik belum terlalu dicemari polutan didukung oleh pohonpohon di pekarangan, memberi suasana segar dan kelimpahan oksigen.

Bagian tanaman yang banyak dimanfaatkan adalah daun (Gambar 2b). Daun merupaka tempat terjadinya fotositesis sehingga banyak mengandung komponen aktif. Pemanfaatan bagian daun sebagi obat dan sayur hal ini diduga karena pada bagian daun banyak ditemukan senyawa metabolit sekunder yang berguna sebagai obat seperti, alkaloid, minyak atsiri, seperti tannin dan senyawa organik lainnya yang tersimpan di vakuola daun ataupun pada jaringan tambahan pada daun seperti trikoma (Patimah 2010). Selain sebagai obat dan sayur salah satu bagian tumbuhan yang menarik yang juga bewarna adalah daun sehingga bervariasinya daun dapat juga dijadikan tanaman hias.

Berdasarkan pemanfaatan didapatkan bahwa tanaman pekarangan banyak dimanfaatkan sebagai bahan pangan sebanyak 78 spesies, selanjutnya untuk hiasan 75 spesies (Gambar 2c). Semua masyarakat memahami dengan sempurna tentang pemenuhan gizi dari pemanfaatan pekarangan sehingga dominanya pemanfaatan untuk pangan, kata pangan ini mencakup sayur, buah, dan rempah.

Ketergantungan dengan bahan pangan membuat masyarakat banyak menanam tanaman pangan untuk memenuhi kebutun tubuh, baik dari segi vitamin, rasa dan berbagai zat yang dibutuhkan tubuh. Oleh karena perlunya penguatan ketahanan pangan keluarga secara signifikan agar mampu mengatasi permasalahan ketahanan pangan secara umum (Dwiratna 2016).

Hasil tanaman buah, sayuran,
dikonsumsi menghemat pengeluaran keluarga, serta ada beberapa spesies jika hasilnya lebih dari keperluan sehari-hari maka dapat dijual ke pasar ataupun tetangga. Beberapa spesies tanaman dapat dimanfaatkan atau dikonsumsi keluarga, yaitu buah, sayuran, obat, rempah. Beberapa pemilik pekarangan membiarkan tanaman herbal/rempah dimanfaatkan sesama warga yang membutuhkan tanpa harus dibayar, sehingga terjalinnya interaksi sosial dan berbagi resep ramuan sehat herbal.

Tingginya keragaman spesies tanaman hias di Desa Taripa sehrusnya dapat dimanfaatkan sebagai ladang pencaharian bagi penduduk, namun minimnya pengetahuan penduduk akan pasar online membuat tanaman hias dipekarangan hanya sebagai pembantu kelestari dan asrinya pekarangan. Untuk pasaran tanaman hias sekarang sebenarnya cukup menjanjikan.

Tanaman obat sendiri sebenarnya juga beragam namun minimnya pengetahuan penduduk dan lebih mengandalkan obat dokter membuat pengembangan tanaman obat di Desa Taripa kurang. Kebanyakan yang lebih memahami tanaman obat-obatan adalah orangtua sementara untuk keluarga muda masi minim pengetahuan tentang resep obat leluhur dan hanya menggunakan tanaman yang terkeal akan khasiat obatnya atau hanya diperuntukan sebagai tanaman obat saja.

Memanfaatkan pekarangan secara optimal dalam bidang kesehatan tentu mempunyai banyak keuntungan bagi masyarakat sendiri, yakni meningkatan pendapatan keluarga misalnya warung hidup, apotek hidup. Kenyataan saat ini, bahwa harga obat di daerah pedesaan tergolong sangat tinggi dibandingan daerah perkotaan, tidak lengkapnya jenis obat, apotek sering tutup dan lebih sering lagi dokter tidak ada. Oleh karena itu penyediaan tanaman yang berfungsi sebagai obat herbal di pekarangan sangat membantu keluarga mengatasi masalah kesehatan (Duaja et al. 2011).

Pekarangan sebagai fungsi ekonomi dimanfaatkan penduduk untuk menambah penghasilan keluarga. Fungsi ekonomi pekarangan ini sudah berjalan baik namun perlu ditingkatkan lagi. Tanaman herbal dan sayuran, selain memberikan hasil untuk dikomsumsi keluarga, dapat memberikan estetika pada pekarangan jika dirancang dengan baik. Selain sebagai pelengkap budi daya pertanian di ekosistem pekarangan. 


\section{Kesimpulan}

Tanaman pekarangan di Desa Taripa didapatkan sebanyak 64 famili yang terdiri dari 155 spesies dan 1265 individu. Famili yang banyak ditemukan jumlah spesiesnya adalah Araceae, sedangkan spesies yang memiliki kelimpahan tertinggi Garcinia mangostana. Kelimpahan spesies pekarangan tertinggi terdapat pada lahan pekarangan luas. Indek kekayaan dan keanekaragaman spesies tanaman tertinggi ditemukan pada lahan pekarangan sempit, sedangkan indek kemerataan spesies tertinggi pada lahan pekarangan sedang. Berdasarkan bentuk hidup tanaman yang banyak dimanfaatkan adalah habitus herba. Bagian tananaman yang banyak dimanfaatkan adalah daun, sedangkan pemanfaatan tanaman pekarangan banyak dimanfaatkan sebagai bahan pangan.

\section{DAFTAR PUSTAKA}

Arifin HS, Munandar A, Arifin NHS, Kaswanto RL (2009) Pemanfaatan pekarangan di perdesaan. Edisi ke-dua. IPB Press, Bogor.

Abdiyani S (2008) Keanekaragaman jenis tumbuhan bawah berkhasiat obat di Dataran Tinggi Dieng. Jurnal Penelitian Hutan dan Konservasi Alam 5(1): 79-92.

Carpenter PL, Theodore DW (1990) Plants in the landscape. Second edition. Waveland Press Inc, USA (US).

Chen LG, Yang LL, Wang CC (2008) AntiInflamantry activity of mangosteen from Garcinia mangostana. Food Chem Toxicol 46: 688-693.

Chomnawang ST, Surasmo S, Wongsaria K, Bunyapraphatsara N (2009) Antibacterial activity of Thai medicinal plants against methicillinresistant Staphylococcus aureus. Fitoterapia 80 (2): 102-4.

Duaja MD, Kartika E, Mukhlis F (2011) Pemberdayaan wanita dalam pemanfaatan pekarangan dengan tanaman obat keluarga (TOGA). Jurnal Pengabdian Pada Masyarakat 52: 7479.
Dwiratna NPS, Widyasanti A, Rahmah DM (2016) Pemanfaatan lahan pekarangan dengan menerapkan konsep kawasan rumah pangan lestari. Dharmakarya: Jurnal Aplikasi Ipteks untuk Masyarakat 5(1):19-22.

Fachrul MF (2012) Metode Sampling Bioekologi. Bumi Aksar, Jakarta.

Galluzzi G, Eyzaguirre P, Negri V (2010) Home gardens: neglected hotspots of agro-biodiversity and cultural diversity. Biodivers Conserv. 19: 3635-3654.

Kasso M, Balakrishnan M (2013) Ex situ conservation of biodiversity with particular emphasis to Ethiopia. Hindawi Publishing Corporation ISRN Biodiversity 2013:1-12.

Karina S (2014) Jenis tumbuhan berguna pada pekarangan masyarakat percampuran di Kelurahan Layana Indah Kecamatan Palu Timur Sulawesi Tengah. Biocelebes 8(2): 01-12.

Mukarlina, Linda R, Nurlaila N (2014) Keanekaragaman Jenis Tanaman Pekarangan di Desa Pahauman Kecamatan Sengah Temila Kabupaten Landak, Kalimantan Barat. Saintifika, 16(1): 51-62.

Magurran A (2004) Measuring Biological Diversity. Blackwell Publishing. New York.

Mitchell R, Hanstad T (2004) Small homegarden plots and sustainable livelihoods for the poor. LSP Working Paper 11. Food and Agriculture Organization of the United Nations, Rome, Italy.

Odum EP (1993) Dasar-Dasar Ekologi. Terjemahan Tjahjono salinan dari buku Fundamental of Ecology. Gadjah Mada University Press, Yogyakarta.

Obolskiy D, Pischel I, Siriwatanametanon N, Heinrich M (2009) Garcinia mangostana L.: a phytochemical and pharmacological review. Phytotherapy Research 23(8): 1047-1065.

Patimah (2010) Keanekaragaman tumbuhan obat di Kawasan Hutan Gunung Sinabung Kabupaten Karo 
Sumatera Utara. [Skripsi]. Fakultas Matematika dan Ilmu Pengetahuan Alam Universitas Sumetera Utara, Medan.

Pandey CB, Rai RB, Singh L, Singh AK (2007) Homegardens of Andaman and Nicobar. India. Agricultur System 2(3): 1-22.

Pendong EF, Arrinjani (2004) Keanekaragaman tanaman pekarangan di Kota Tomohon, Sulawesi Utara. Biosmart 6(1): 44-45.

Rahayu M (2005) Pengetahuan dan pemanfaatan tumbuhan obat oleh masyarakat kaili sekitar Taman Nasional Lore Lind, Sulawesi Tengah. Jurnal Bahan Alam Indonesia 4 (1):1412- 2855.

Silalahi M (2018) Keanekaragaman tumbuhan pekarangan dan pemanfaatannya untuk prasarana pembelajaran di Sekolah PSKD 1 Jakarta sebagai salah satu usaha konservasi. EduMatSains 3 (1): 1-20.
Sinaga KA, Murningsih, Jumari (2017) Identifikasi talas-talasan edible (Araceae) di Semarang, Jawa Tengah. Bioma 19 (1): 18-21.

Soewito (1987) Memanfaatkan pekarangan. CV Titik Terang, Jakarta.

Sihotang H, Silalahi M, Simalango EM (2019) Manajamen tanaman di Nurseri Kranggan, Bekasi, Jawa Barat. ejournal 6(1): 89-101.

Widiastuti A, Sobir S, Suhartanto MR (2010). Analisis keragaman manggis (Garcinia mangostana) diiradiasi dengan sinar gamma berdasarkan karakteristik morfologi dan anatomi. Bioteknologi

Biotechnological Studies 7(2), 23-33.

Zurriyati Y, Dahono (2016) Keragaman sumber daya genetik tanaman buahbuahan eksotik di Kabupaten Binta, Provinsi Kepulauan Riau. Buletin Plasma Nutfah 22 (1): 11-20. 


\section{Lampiran 1. Tabel Famili dan spesies tanaman pekarangan di Desa Taripa}

\begin{tabular}{|c|c|c|c|c|c|c|c|c|}
\hline \multirow{2}{*}{ NO } & \multirow{2}{*}{ Family } & \multirow{2}{*}{ Nama Indonesia } & \multirow{2}{*}{ Nama Ilmiah } & \multicolumn{3}{|c|}{ Kategori } & \multirow{2}{*}{ Jumlah } & Persen \\
\hline & & & & Luas & Sedang & Sempit & & remsen \\
\hline 1 & Clusiaceae & Manggis & Garcinia mangostana $\mathrm{L}$. & 21 & 13 & 14 & 48 & 3,79 \\
\hline 2 & Zingiberaceae & Kunyit & Curcuma longa $\mathrm{L}$ & 14 & 10 & 13 & 37 & 2,92 \\
\hline 3 & Meliaceae & Langsat & Lansium domesticum Corrêa & 15 & 11 & 10 & 36 & 2,85 \\
\hline 4 & Apiaceae & Seledri & Apium graveolens $\mathrm{L}$ & 12 & 7 & 14 & 33 & 2,61 \\
\hline 5 & Zingiberaceae & Jahe & Zingiber officinale Rosc & 12 & 8 & 13 & 33 & 2,61 \\
\hline 6 & Liliaceae & Daun bawang & Allium fistulosum $\mathrm{L}$ & 9 & 9 & 13 & 31 & 2,45 \\
\hline 7 & Caricaceae & Pepaya & Carica papaya $\mathrm{L}$ & 14 & 5 & 10 & 29 & 2,29 \\
\hline 8 & Rutaceae & Jeruk nipis & Citrus aurantifolia (Christm.) Swingle, orth & 11 & 6 & 12 & 29 & 2,29 \\
\hline 9 & Euphorbiaceae & Puring & Codiaeum variegatum (L.) A. Juss & 10 & 9 & 8 & 27 & 2,13 \\
\hline 10 & Agavaceae & Lidah mertua & Sansevieria trifasciata Hort. ex Prain & 9 & 7 & 10 & 26 & 2,06 \\
\hline 11 & Lamiaceae & Kemangi & Ocimum basilicum $\mathrm{L}$ & 4 & 10 & 12 & 26 & 2,06 \\
\hline 12 & Poaceae & Serei & Cymbopogon citratus (DC.) Stapf & 6 & 12 & 8 & 26 & 2,06 \\
\hline 13 & Araceae & Aglonema evergreen & Aglaonema commutatum Schott & 9 & 7 & 7 & 23 & 1,82 \\
\hline 14 & Begoniaceae & Bunga anggur & Begonia cucullata Willd & 10 & 5 & 8 & 23 & 1,82 \\
\hline 15 & Bombacaceae & Durian & Durio zibethinus Murray & 11 & 5 & 7 & 23 & 1,82 \\
\hline 16 & Amaryllidaceae & Lokio & Allium schoenoprasum $\mathrm{L}$ & 5 & 8 & 9 & 22 & 1,74 \\
\hline 17 & Solanaceae & Cabai rawit & Capsicum frutescens $\mathrm{L}$ & 7 & 8 & 7 & 22 & 1,74 \\
\hline 18 & Solanaceae & Tomat & Solanum lycopersicum $\mathrm{L}$ & 5 & 7 & 10 & 22 & 1,74 \\
\hline 19 & Musaceae & Pisang & Musa paradisiaca $\mathrm{L}$ & 9 & 7 & 5 & 21 & 1,66 \\
\hline 20 & Solanaceae & Terong & Solanum melongena $\mathrm{L}$ & 6 & 9 & 6 & 21 & 1,66 \\
\hline 21 & Araceae & Aglonema crispum & Aglaonema crispum (Pit. \& Man.) D.H.Nicol & 6 & 4 & 8 & 18 & 1,42 \\
\hline 22 & Anacardiaceae & Mangga & Mangifera indica $\mathrm{L}$ & 12 & 1 & 3 & 16 & 1,26 \\
\hline 23 & Convolvulaceae & Ubi jalar & Ipomoea batatas (L.) Lam & 7 & 7 & 2 & 16 & 1,26 \\
\hline 24 & Marantaceae & Kalatea & Calathea lietzei E.Morren & 4 & 7 & 5 & 16 & 1,26 \\
\hline 25 & Araceae & Keladi & Caladium bicolor (W.Ait.) Vent & 4 & 7 & 4 & 15 & 1,19 \\
\hline 26 & Sterculiaceae & Cacao & Theobroma cacao $\mathrm{L}$ & 5 & 5 & 5 & 15 & 1,19 \\
\hline 27 & Araceae & Gelombang cinta & Anthurium plowmanii Croat & 5 & 5 & 4 & 14 & 1,11 \\
\hline 28 & Arecaceae & Kelapa & Cocos nucifera $\mathrm{L}$ & 8 & 2 & 4 & 14 & 1,11 \\
\hline 29 & Euphorbiaceae & Ubi kayu & Manihot esculenta Crantz & 7 & 2 & 5 & 14 & 1,11 \\
\hline 30 & Myrtaceae & Cengkeh & Syzygium aromaticum (L.) Merr. \& L. M. Perry & 8 & 4 & 2 & 14 & 1,11 \\
\hline 31 & Orchidaceae & Vanili & Vanilla planifolia Andrew & 8 & 4 & 2 & 14 & 1,11 \\
\hline 32 & Annonaceae & Sirsak & Annona muricata $\mathrm{L}$ & 6 & 3 & 4 & 13 & 1,03 \\
\hline 33 & Araceae & Dolar & Zamioculcas Zamiifolia (Lodd.) Engl & 7 & 1 & 5 & 13 & 1,03 \\
\hline 34 & Asphodelaceae & Lida buaya & Aloe vera $(\mathrm{L}$.) Burm. $\mathrm{f}$ & 4 & 0 & 9 & 13 & 1,03 \\
\hline 35 & Pandanaceae & Pandan & Pandanus amaryllifolius Roxb & 7 & 3 & 3 & 13 & 1,03 \\
\hline 36 & Myrtaceae & Jambu biji & Psidium guajava $\mathrm{L}$ & 5 & 4 & 3 & 12 & 0,95 \\
\hline 37 & Piperaceae & Merica & Piper nigrum $\mathrm{L}$ & 3 & 2 & 7 & 12 & 0,95 \\
\hline 38 & Rubiaceae & Asoka & Ixora acuminata Roxb & 5 & 3 & 4 & 12 & 0,95 \\
\hline 39 & Apocynaceae & Tapak dara & Catharanthus roseus (L.) G. Don & 6 & 1 & 3 & 10 & 0,79 \\
\hline 40 & Araceae & Kuping gajah & Anthurium crystallinum Linden \& André & 5 & 3 & 2 & 10 & 0,79 \\
\hline 41 & Cactaceae & Buah naga & Hylocereus undatus (Haw.) Britton \& Rose & 2 & 2 & 6 & 10 & 0,79 \\
\hline 42 & Costaceae & Pacing tawar & Cheilocostus speciosus & 3 & 2 & 5 & 10 & 0,79 \\
\hline 43 & Cucurbitaceae & Labu siam & Sechium edule (Jacq.) Sw & 2 & 6 & 2 & 10 & 0,79 \\
\hline 44 & Oxalidaceae & Kupu-kupu & Oxalis triangularis & 5 & 4 & 1 & 10 & 0,79 \\
\hline 45 & Asteraceae & Kenikir & Cosmos caudatus Kunth & 2 & 6 & 1 & 9 & 0,71 \\
\hline 46 & Brassicaceae & Sawi & Brassica rapa var. parachinensis $\mathrm{L}$ & 4 & 2 & 3 & 9 & 0,71 \\
\hline 47 & Liliaceae & Oktober & Hippeastrum $\mathrm{sp}$ & 2 & 3 & 4 & 9 & 0,71 \\
\hline 48 & Amaranthaceae & Bunga bayam & Amaranthus tricolor $\mathrm{L}$ & 3 & 1 & 4 & 8 & 0,63 \\
\hline 49 & Araceae & Lili perdamaian & Spathiphyllum wallisii & 3 & 3 & 2 & 8 & 0,63 \\
\hline 50 & Arecaceae & Enau & Arenga pinnata Merr & 1 & 4 & 3 & 8 & 0,63 \\
\hline 51 & Arecaceae & Palem & Dypsis lutescens (H. Wendl.) Beentje \& Dransf & 1 & 3 & 4 & 8 & 0,63 \\
\hline 52 & Aspleniaceae & Sarang burung & Asplenium nidus Linn & 5 & 2 & 1 & 8 & 0,63 \\
\hline 53 & Basellaceae & Binahong & Anredera cordifolia (Ten.) Steenis & 4 & 3 & 1 & 8 & 0,63 \\
\hline 54 & Bromeliaceae & Bromelia & Bromelia $\mathrm{sp}$ & 2 & 4 & 2 & 8 & 0,63 \\
\hline 55 & Bromeliaceae & Nenas & Ananas comosus (L.) Merr & 3 & 4 & 1 & 8 & 0,63 \\
\hline 56 & Fabaceae & Kacang panjang & Vigna sinensis (L.) Savi ex Hassk & 4 & 2 & 2 & 8 & 0,63 \\
\hline 57 & Lamiaceae & Mayana & Coleus atropurpureus (L) Benth & 1 & 2 & 5 & 8 & 0,63 \\
\hline 58 & Amaranthaceae & Bayam tanah & Amaranthus blitum Miq & 4 & 2 & 1 & 7 & 0,55 \\
\hline 59 & Apocynaceae & Kamboja & Adenium obesum (Forssk.) Roem. \& Schult & 3 & 2 & 2 & 7 & 0,55 \\
\hline 60 & Cactaceae & Kaktus centong & Opuntia cochenillifera (L.) Mill & 3 & 2 & 2 & 7 & 0,55 \\
\hline 61 & Malvaceae & Gedi & Abelmoschus manihot (L.) Medik & 4 & 2 & 1 & 7 & 0,55 \\
\hline 62 & Myrtaceae & Bunga cingke & Eugenia $\mathrm{sp}$ & 3 & 1 & 3 & 7 & 0,55 \\
\hline 63 & Oxalidaceae & Belimbing wuluh & Averrhoa bilimbi $\mathrm{L}$ & 5 & 1 & 1 & 7 & 0,55 \\
\hline 64 & Portulacaceae & Pukul sembilan & Portulaca grandiflora Hook & 4 & 1 & 2 & 7 & 0,55 \\
\hline 65 & Zingiberaceae & Lengkuas & Alpinia galanga (L.) Sw & 2 & 2 & 3 & 7 & 0,55 \\
\hline 66 & Lauraceae & Alpukat & Persea americana P. Mill & 4 & 0 & 2 & 6 & 0,47 \\
\hline 67 & Liliaceae & Kucai & Allium tuberosum Rottl. ex Spreng & 0 & 2 & 4 & 6 & 0,47 \\
\hline 68 & Solanaceae & Cepokak & Solanum torvum $\mathrm{Sw}$ & 5 & 1 & 0 & 6 & 0,47 \\
\hline 69 & Araceae & Air mata bunda & Dieffenbachia $\mathrm{sp}$ & 0 & 4 & 1 & 5 & 0,40 \\
\hline 70 & Araceae & Talas & Colocasia esculenta var. antiquorum (L.) Schott & 3 & 1 & 1 & 5 & 0,40 \\
\hline 71 & Convolvulaceae & Kangkung & Ipomoea reptana Poir & 2 & 2 & 1 & 5 & 0,40 \\
\hline 72 & Euphorbiaceae & Balacai & Jatropha curcas L & 2 & 2 & 1 & 5 & 0,40 \\
\hline 73 & Liliaceae & Andong & Cordyline fruticosa (L.) A.Chev & 1 & 2 & 2 & 5 & 0,40 \\
\hline 74 & Malvaceae & Kembang sepatu & Hibiscus rosa-sinensis $\mathrm{L}$ & 1 & 0 & 4 & 5 & 0,40 \\
\hline 75 & Poaceae & Tebu & Saccharum officinarum $\mathrm{L}$ & 5 & 0 & 0 & 5 & 0,40 \\
\hline
\end{tabular}




\begin{tabular}{|c|c|c|c|c|c|c|c|c|}
\hline 76 & Rubiaceae & Kopi & Coffea canephora Pierre ex Froehner & 0 & 1 & 4 & 5 & 0,40 \\
\hline 77 & Araceae & Janda sobek & Monstera deliciosa Liebm & 0 & 3 & 1 & 4 & 0,32 \\
\hline 78 & Balsaminaceae & Pacar air & Impatiens balsamina $\mathrm{L}$ & 1 & 1 & 2 & 4 & 0,32 \\
\hline 79 & Elaeocarpaceae & Kersen & Muntingia calabura $\mathrm{L}$ & 1 & 2 & 1 & 4 & 0,32 \\
\hline 80 & Euphorbiaceae & Eforbia & Euphorbia milii Des Moul & 2 & 0 & 2 & 4 & 0,32 \\
\hline 81 & Euphorbiaceae & Penicillin & Jatropha multifida $\mathrm{L}$ & 1 & 3 & 0 & 4 & 0,32 \\
\hline 82 & Hydrangeaceae & Hortensia & Hydrangea macrophylla (Thunb.) Ser & 1 & 0 & 3 & 4 & 0,32 \\
\hline 83 & Marantaceae & Lerek & Phrynium pubinerve Blume & 2 & 1 & 1 & 4 & 0,32 \\
\hline 84 & Myristicaceae & Pala & Myristica fragrans Houtt & 2 & 2 & 0 & 4 & 0,32 \\
\hline 85 & Nyctaginaceae & Bugenvil & Bougainvillea glabra Choisy & 2 & 0 & 2 & 4 & 0,32 \\
\hline 86 & Orchidaceae & Anggrek lilin & Aerides odoratum Reinw. ex Blume & 2 & 0 & 2 & 4 & 0,32 \\
\hline 87 & Passifloraceae & Markisa & Passiflora edulis Sims & 2 & 0 & 2 & 4 & 0,32 \\
\hline 88 & Pontederiaceae & Eceng gondok & Eichhornia crassipes (Mart.) Solms & 0 & 2 & 2 & 4 & 0,32 \\
\hline 89 & Rosaceae & Stroberi & Fragaria ananassa (Weston) & 0 & 1 & 3 & 4 & 0,32 \\
\hline 90 & Rutaceae & Jeruk purut & Citrus hystrix $\mathrm{Dc}$ & 1 & 3 & 0 & 4 & 0,32 \\
\hline 91 & Zingiberaceae & Kecombrang & Etlingera elatior (Jack) R. M. Sm & 3 & 1 & 1 & 4 & 0,32 \\
\hline 92 & Cactaceae & Kaktus spiral & Mammillaria tolimensis R. T. Craig & 1 & 0 & 2 & 3 & 0,24 \\
\hline 93 & Commelinaceae & Zebrina & Tradescantia zebrina hort. ex Bosse & 1 & 1 & 1 & 3 & 0,24 \\
\hline 94 & Crassulaceae & Cocor bebek & Bryophyllum calycinum Salisb & 2 & 0 & 1 & 3 & 0,24 \\
\hline 95 & Cucurbitaceae & Ketimun & Cucumis sativus $\mathrm{L}$ & 0 & 1 & 2 & 3 & 0,24 \\
\hline 96 & Euphorbiaceae & Pata tulang & Euphorbia tirucalli $\mathrm{L}$ & 1 & 1 & 1 & 3 & 0,24 \\
\hline 97 & Lamiaceae & Daun mint & Mentha sp & 0 & 0 & 3 & 3 & 0,24 \\
\hline 98 & Liliaceae & Lili paris & Chlorophytum comosum var. vittatum (Thunb.) Baker & 1 & 1 & 1 & 3 & 0,24 \\
\hline 99 & Moraceae & Kopiak & Ficus dammaropsis & 3 & 0 & 0 & 3 & 0,24 \\
\hline 100 & Moraceae & Nangka & Artocarpus heterophyllus Lam & 1 & 0 & 2 & 3 & 0,24 \\
\hline 101 & Myrtaceae & Jambu air & Syzygium aqueum (Burm. f.) Alston & 2 & 1 & 0 & 3 & 0,24 \\
\hline 102 & Poaceae & Bambu & Bambusa sp & 2 & 0 & 1 & 3 & 0,24 \\
\hline 103 & Pteridaceae & Suplir & Adiantum peruvianum Klotzsch & 2 & 0 & 1 & 3 & 0,24 \\
\hline 104 & Rosaceae & Mawar & Rosa hybrida & 1 & 1 & 1 & 3 & 0,24 \\
\hline 105 & Rutaceae & Lemon cui & Citrus Microcarpa & 1 & 2 & 0 & 3 & 0,24 \\
\hline 106 & Zingiberaceae & Temulawak & Curcuma xanthorrhiza Roxb & 0 & 2 & 1 & 3 & 0,24 \\
\hline 107 & Acanthaceae & Petunia & Ruellia simplex C.Wright & 0 & 2 & 0 & 2 & 0,16 \\
\hline 108 & Amaranthaceae & Bayam tahun & Amaranthus hybridus L & 1 & 0 & 1 & 2 & 0,16 \\
\hline 109 & Amaranthaceae & Bunga bayam kucing & Celosia argentea $\mathrm{L}$ & 1 & 1 & 0 & 2 & 0,16 \\
\hline 110 & Araceae & Janda bolong & Monstera adansonii Schott & 0 & 2 & 0 & 2 & 0,16 \\
\hline 111 & Arecaceae & Pinang & Areca catechu $\mathrm{L}$ & 2 & 0 & 0 & 2 & 0,16 \\
\hline 112 & Asteraceae & Matahari & Helianthus anпииs $\mathrm{L}$ & 0 & 1 & 1 & 2 & 0,16 \\
\hline 113 & Asteraceae & Sambung nyawa & Gynura procumbens (Lour.) Merr & 0 & 1 & 1 & 2 & 0,16 \\
\hline 114 & Cucurbitaceae & Labu kuning & Cucurbita moschata Duchesne & 2 & 0 & 0 & 2 & 0,16 \\
\hline 115 & Fabaceae & Bunga kacang & Arachis pintoi Krapov. \& W.C.Greg & 0 & 0 & 2 & 2 & 0,16 \\
\hline 116 & Fabaceae & Kacang tanah & Arachis hypogaea $\mathrm{L}$ & 1 & 0 & 1 & 2 & 0,16 \\
\hline 117 & Fabaceae & Kecipir & Psophocarpus tetragonolobus (L.) DC & 0 & 2 & 0 & 2 & 0,16 \\
\hline 118 & Liliaceae & Amarilis & Proiphys amboinensis (L.) Herb & 0 & 0 & 2 & 2 & 0,16 \\
\hline 119 & Pinaceae & Pinus & Pinus merkusii Jungh. \& Vriese ex Vriese & 1 & 0 & 1 & 2 & 0,16 \\
\hline 120 & Rutaceae & Kemuning & Murraya paniculata L.Â Jack & 0 & 0 & 2 & 2 & 0,16 \\
\hline 121 & Rutaceae & Lemon nipis & Citrus limon (L.) Burm. $\mathrm{f}$ & 0 & 0 & 2 & 2 & 0,16 \\
\hline 122 & Sapindaceae & Rambutan & Nephelium lappaceum L & 1 & 1 & 0 & 2 & 0,16 \\
\hline 123 & Verbenaceae & Arogo & Premna oblongifolia Merr & 0 & 2 & 0 & 2 & 0,16 \\
\hline 124 & Verbenaceae & Topi cina & Holmskioldia sanguinea Retz & 0 & 1 & 1 & 2 & 0,16 \\
\hline 125 & Acanthaceae & Melati jepang & Pseuderanthemum carruthersii (Seem.) Guillaumin & 0 & 0 & 1 & 1 & 0,08 \\
\hline 126 & Agavaceae & Lagu india & Dracaena reflexa Lam & 0 & 1 & 0 & 1 & 0,08 \\
\hline 127 & Agavaceae & Rejeki & Dracaena sanderiana Sander ex Mast & 1 & 0 & 0 & 1 & 0,08 \\
\hline 128 & Amaranthaceae & Kancing lurah & Gomphrena globosa $\mathrm{L}$ & 1 & 0 & 0 & 1 & 0,08 \\
\hline 129 & Anacardiaceae & Kedondong & Spondias dulcis Parkinson & 0 & 0 & 1 & 1 & 0,08 \\
\hline 130 & Apocynaceae & Alamanda & Allamanda cathartica $\mathrm{L}$ & 1 & 0 & 0 & 1 & 0,08 \\
\hline 131 & Araceae & Kuping rusa & Alocasia amazonica & 0 & 1 & 0 & 1 & 0,08 \\
\hline 132 & Asteraceae & Dahlia & Dahlia pinnata $\mathrm{Cav}$ & 0 & 1 & 0 & 1 & 0,08 \\
\hline 133 & Asteraceae & Krisan india & Chrysanthemum indicum $\mathrm{L}$ & 0 & 0 & 1 & 1 & 0,08 \\
\hline 134 & Asteraceae & Seruni & Leucanthemum maximum (Ramond) DC & 1 & 0 & 0 & 1 & 0,08 \\
\hline 135 & Asteraceae & Zinnia & Zinnia $\mathrm{sp}$ & 1 & 0 & 0 & 1 & 0,08 \\
\hline 136 & Brassicaceae & Kol & Brassica oleracea $\mathrm{L}$ & 0 & 0 & 1 & 1 & 0,08 \\
\hline 137 & Combretaceae & Ketapang & Terminalia catappa $\mathrm{L}$ & 0 & 0 & 1 & 1 & 0,08 \\
\hline 138 & Cycadaceae & Penawar jambe & Cycas revoluta Thunb & 1 & 0 & 0 & 1 & 0,08 \\
\hline 139 & Dryopteridaceae & Pakis & Nephrolepis cordifolia (L.) C. Presl & 0 & 0 & 1 & 1 & 0,08 \\
\hline 140 & Euphorbiaceae & Ekor kucing & Acalypha hispida Burm.F & 1 & 0 & 0 & 1 & 0,08 \\
\hline 141 & Lamiaceae & Selasih & Ocimum $\mathrm{sp}$ & 0 & 1 & 0 & 1 & 0,08 \\
\hline 142 & Liliaceae & Bawang merah & Allium cepa var. aggregatum $\mathrm{L}$ & 0 & 0 & 1 & 1 & 0,08 \\
\hline 143 & Liliaceae & Suji & Pleomele angustifolia N.E.Brown & 0 & 1 & 0 & 1 & 0,08 \\
\hline 144 & Liliaceae & Tulip & Tulipa sp & 1 & 0 & 0 & 1 & 0,08 \\
\hline 145 & Mimosaceae & Jengkol & Archidendron pauciflorum (Benth.) Nielsen & 0 & 0 & 1 & 1 & 0,08 \\
\hline 146 & Myrtaceae & Jambu air mawar & Syzygium samarangense (Blume) Merr. \& L.M. Perry & 0 & 0 & 1 & 1 & 0,08 \\
\hline 147 & Oxalidaceae & Belimbing & Averrhoa carambola $\mathrm{L}$ & 0 & 0 & 1 & 1 & 0,08 \\
\hline 148 & Piperaceae & Telinga tikus & Peperomia $\mathrm{sp}$ & 0 & 1 & 0 & 1 & 0,08 \\
\hline 149 & Poaceae & Jagung & Zea mays $\mathrm{L}$ & 0 & 1 & 0 & 1 & 0,08 \\
\hline 150 & Poaceae & Rumput jepang & Zoysia tenuifolia Willd. ex Thiele & 0 & 0 & 1 & 1 & 0,08 \\
\hline 151 & Rubiaceae & Jati & Guettarda speciosa $\mathrm{L}$ & 0 & 0 & 1 & 1 & 0,08 \\
\hline 152 & Rutaceae & Jeruk bali & Citrus maxima (Burm. f.) Merr & 0 & 1 & 0 & 1 & 0,08 \\
\hline 153 & Sapindaceae & Kelengkeng & Dimocarpus longan Lour & 0 & 1 & 0 & 1 & 0,08 \\
\hline 154 & Verbenaceae & Leilem & Clerodendrum minahassae Teijsm at binn & 0 & 1 & 0 & 1 & 0,08 \\
\hline \multirow[t]{2}{*}{155} & Verbenaceae & Pecut kuda & Stachytarpheta jamaicensis (L.) Vahl & 0 & 1 & 0 & 1 & 0,08 \\
\hline & & & Total & 474 & 365 & 426 & 1265 & 100 \\
\hline
\end{tabular}




\section{Lampitran 2. Tabel Pemanfaatan tanaman pekarangan di Desa Taripa, Kecamatan Pamon Timur, K abupaten Poso, Sulawesi Tengah}

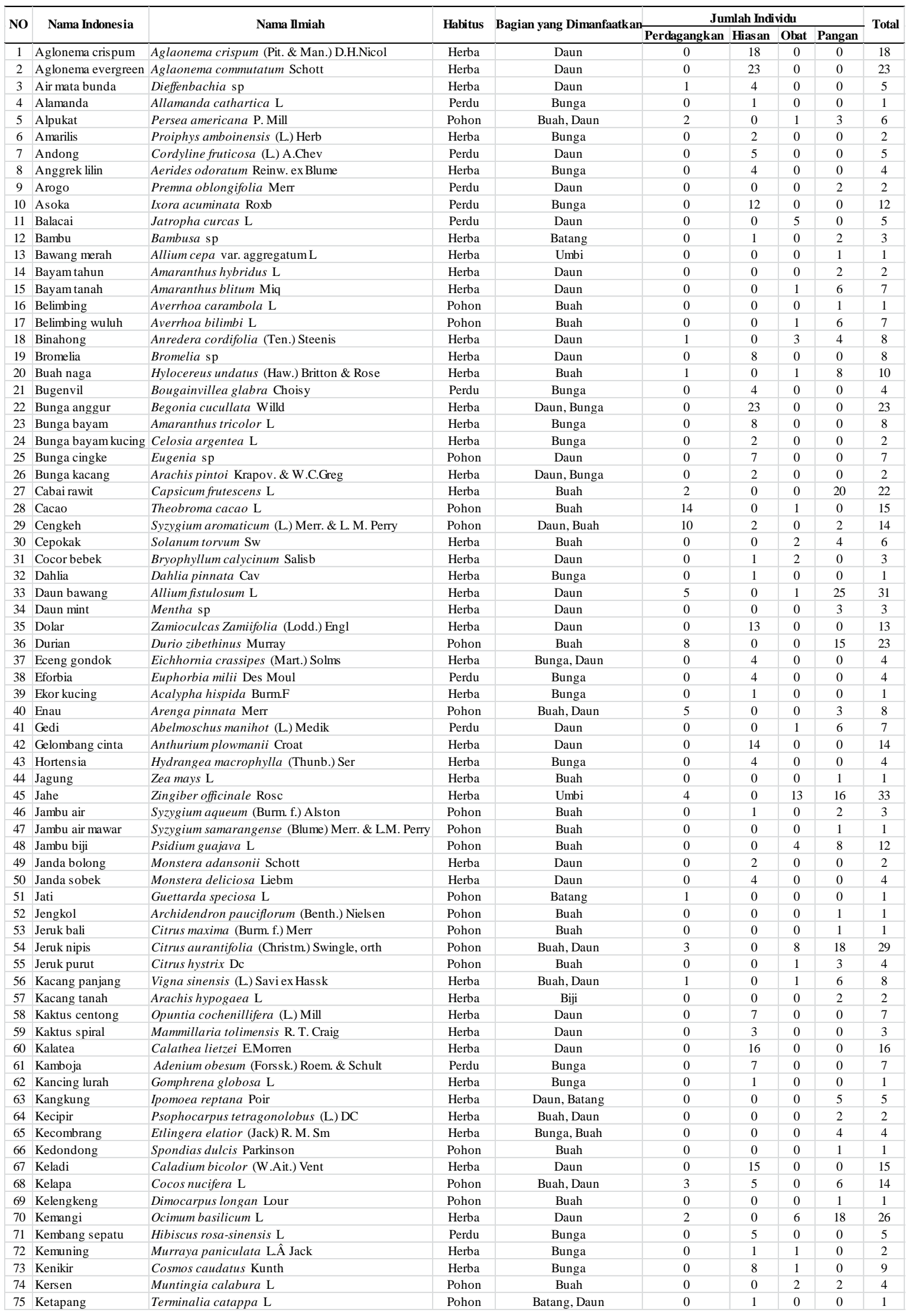




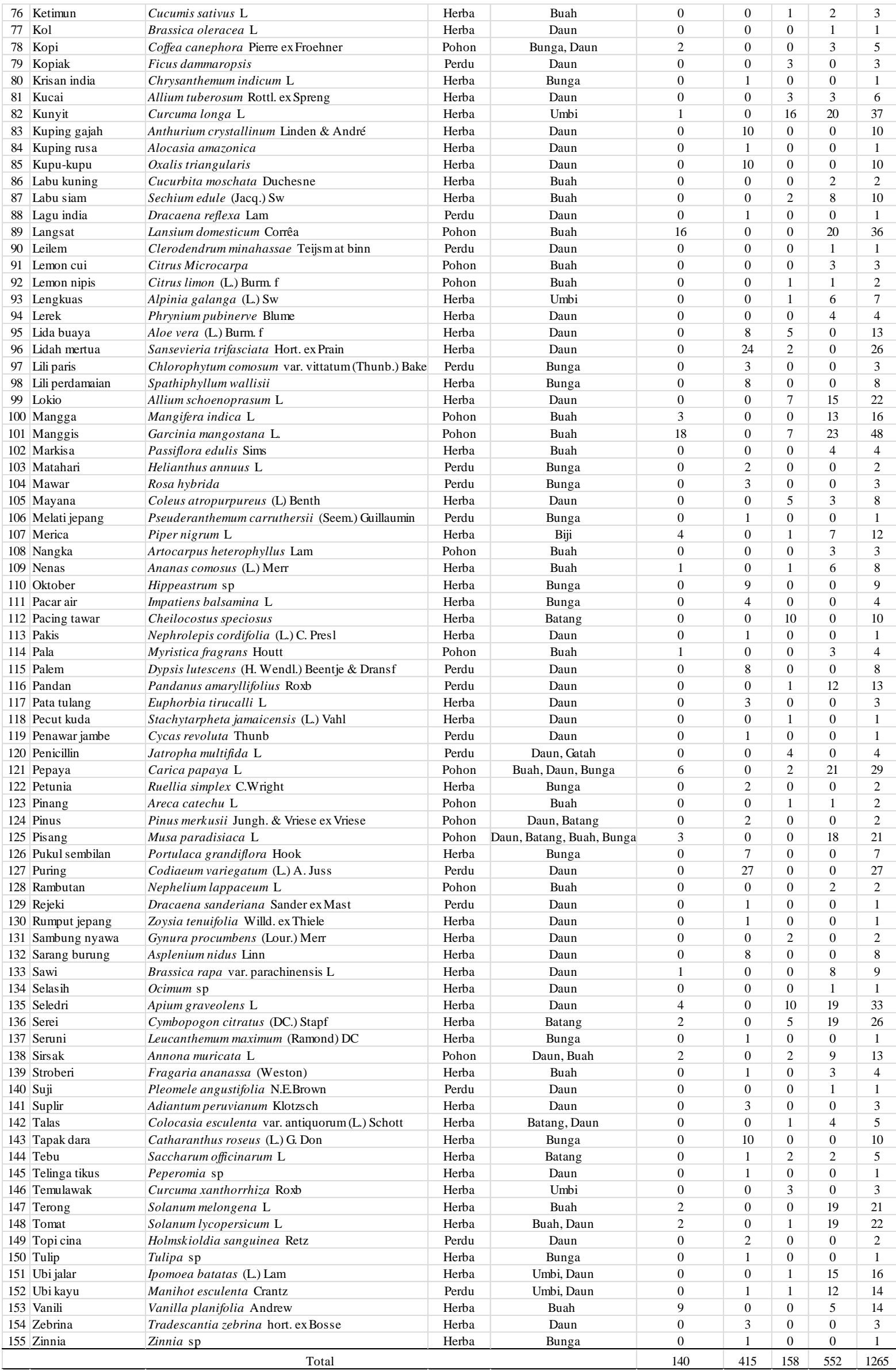

